INFLAMMATORY BOWEL DISEASE

\title{
Deficient host-bacteria interactions in inflammatory bowel disease? The toll-like receptor (TLR)-4 Asp299gly polymorphism is associated with Crohn's disease and ulcerative colitis
}

\author{
D Franchimont, S Vermeire, H El Housni, M Pierik, K Van Steen, T Gustot, E Quertinmont, \\ M Abramowicz, A Van Gossum, J Devière, P Rutgeerts
}

Gut 2004;53:987-992. doi: 10.1136/gut.2003.030205

See end of article for authors' affiliations

Correspondence to:

Dr D Franchimont,

Department of

Gastroenterology, Erasme

University Hospital, 808,

Lennik St, 1070 Brussels,

Belgium;

Denis.Franchimont@

ulb.ac.be

Accepted for publication

1 January 2004

\begin{abstract}
Background and aims: Elicitation of an innate immune response to bacterial products is mediated through pattern recognition receptors (PRRs) such as the toll-like receptors (TLRs) and the NODs. The recently characterised Asp299Gly polymorphism in the lipopolysaccharide (LPS) receptor TLR4 is associated with impaired LPS signalling and increased susceptibility to Gram negative infections. We sought to determine whether this polymorphism was associated with Crohn's disease (CD) and/or ulcerative colitis (UC).

Methods: Allele frequencies of the TLR4 Asp299Gly polymorphism and the three NOD2/CARD15 polymorphisms (Arg702Trp, Gly908Arg, and Leu1007fsinsC) were assessed in two independent cohorts of CD patients (cohort 1, $n=334$; cohort 2, $n=114$ ), in 163 UC patients, and in 140 controls. A transmission disequilibrium test (TDT) was then performed on 318 inflammatory bowel disease (IBD) trios. Results: The allele frequency of the TLR4 Asp299Gly polymorphism was significantly higher in CD (cohort 1: $11 \%$ v 5\%, odds ratio (OR) 2.31 (95\% confidence interval (Cl) 1.28-4.17), $p=0.004$; and cohort 2: $12 \% \vee 5 \%$, OR $2.45(95 \% \mathrm{Cl} 1.24-4.81), \mathrm{p}=0.007)$ and UC patients (10\% v 5\%, OR 2.05 (95\% Cl $1.07-$ $3.93), p=0.027$ ) compared with the control population. A TDT on 318 IBD trios demonstrated preferential transmission of the TLR4 Asp299Gly polymorphism from heterozygous parents to affected children (T/U: $68 / 34, p=0.01)$. Carrying polymorphisms in both TLR4 and NOD2 was associated with a genotype relative risk (RR) of 4.7 compared with a RR of 2.6 and 2.5 for TLR4 and NOD2 variants separately. Conclusion: We have reported on a novel association of the TLR4 Asp299Gly polymorphism with both CD and UC. This finding further supports the genetic influence of PRRs in triggering IBD.
\end{abstract}

M ounting evidence suggests a pivotal role of the enteric bacterial flora in the pathogenesis of inflammatory bowel disease (IBD). Genetically engineered animals develop colitis when exposed to commensal bacteria but remain disease free when raised in a sterile environment. ${ }^{1}$ The role of faecal stream diversion in Crohn's disease (CD) patients, ${ }^{2}$ the efficacy of antibiotics and probiotics, ${ }^{3}$ and the loss of tolerance to commensal bacteria ${ }^{45}$ further underscore the influence of enteric bacteria in inducing and perpetuating intestinal inflammation. Thus IBD seems to result from a disturbed host-bacterial interaction with an aberrant mucosal immune response. ${ }^{67}$

Elicitation of an innate immune response to bacterial products is mediated through families of pattern recognition receptors (PRRs). These families include a number of soluble, membrane, and cytosolic receptors that recognise pathogen associated molecular patterns of microorganisms through leucine rich repeat (LRR) containing domains. ${ }^{8}$ NODs are cytosolic PRRs involved in intracellular recognition of bacterial products such as lipopolysaccharide (LPS) and peptidoglycan (PGN) derived from Gram negative and positive bacteria, respectively. ${ }^{10}$ Interestingly, NOD2 (also named CARD15) variants are strongly associated with CD. ${ }^{11}{ }^{12}$ Indeed, the frameshift NOD2 variant Leul007fsinsC with a truncated terminal LRR domain and two other NOD2 variants, Gly908Arg and Arg702Trp, lead to deficient LPS and PGN signalling and to reduced nuclear factor $\kappa \mathrm{B}$ activation. ${ }^{12}{ }^{13}$ In fact, detailed biochemical analyses, searching for specific ligands of NOD2, revealed that muramyl dipeptide derived from PGN appears to be the essential structure recognised by NOD2. ${ }^{14}$ Thus defects in LPS and/or PGN signalling seem to impair the innate mucosal immune response, essential to counteract early bacterial invasion, thus leading to mucosal tissue destruction and chronic intestinal inflammation. ${ }^{13}{ }^{15}$

A major inducer of the inflammatory response to Gram negative bacteria is LPS, derived from the outer envelope of these bacteria. Lipopolysaccharride signalling is mainly mediated through the cell surface toll-like receptors (TLRs). ${ }^{16}$ Toll-like receptor 4 (TLR4) is the major transducer of LPS and specifically binds the lipid A portion of LPS. Its targeted deletion abolishes the LPS response in $\mathrm{CEH} / \mathrm{HeJ}$ and C57BL/10ScCR mouse strains. ${ }^{17}$ During intestinal inflammation, intestinal epithelial cells (IECs), macrophages, and dendritic cells express TLR4 which represents the first frontline defence receptor against enteric Gram negative bacteria. ${ }^{18}{ }^{19}$ Interestingly, the recently characterised in vivo TLR4 Asp299Gly polymorphism has been shown to be associated with decreased bronchial responsiveness to LPS in humans. ${ }^{20}$ Patients bearing this polymorphism demonstrate increased

Abbreviations: PRR, pattern recognition receptor; TLR, toll-like receptor; LPS, lipopolysaccharide; CD, Crohn's disease; UC, ulcerative colitis; IBD, inflammatory bowel disease; LRR, leucine rich repeat; PGN, peptidoglycan; IEC, intestinal epithelial cell; TDT, transmission disequilibrium test; IC, indeterminate colitis; ASCA, anti-Saccharomyces cerevisiae antibody; $\mathrm{Bl}$, binding index; SNP, single nucleotide polymorphisms; PCR, polymerase chain reaction; OR, odds ratios; GAR, genotype absolute risk; GRR, genotype relative risk; $R R$, relative risk 
susceptibility to Gram negative infections. ${ }^{21}{ }^{22}$ While a recent study suggested its limited impact on LPS stimulated human monocytes, ${ }^{23}$ this polymorphism, located in the extracellular LRR domain of TLR4, impairs LPS signalling and results in decreased nuclear factor $\kappa \mathrm{B}$ activation in transfection experiments. ${ }^{20}$ Even if a single polymorphism has a relative in vivo penetrance compared with the many other functional gene variants involved in LPS signalling, the TLR4 Asp299Gly polymorphism could produce similar phenotypic consequences to those observed with NOD2 polymorphisms and participate in the pathogenesis of CD. In this paper, we sought to determine whether this polymorphism was associated with CD and/or ulcerative colitis (UC), and examined its impact, alone or in combination with NOD2 polymorphisms, on a particular CD or UC phenotype.

\section{PATIENTS AND METHODS}

\section{Human subjects and phenotypic analyses}

Two populations of CD patients seen at University Hospital Gasthuisberg, Leuven (cohort $1, \mathrm{n}=334$ ) and Erasme Hospital, Brussels (cohort 2, $\mathrm{n}=114$ ) were examined for clinical characteristics, biological markers, and genotype, as well as one cohort of UC patients ( $n=163$, Gasthuisberg) and a control population of blood donors $(n=140$, Gasthuisberg). Almost all CD patients in cohort 1 were White Caucasian (98\%, $\mathrm{n}=328)$; four patients were Ashkenazy Jewish and two Moroccan. In cohort 2, CD patients were as follows: White Caucasian $(93 \%, \mathrm{n}=106)$, Moroccan $(n=6)$, and Ashkenazy Jewish $(n=2)$. Controls and UC patients were all White Caucasian. CD cohort 1 included related patients while cohort 2 did not. In cohort 1 , $192 / 334(57.5 \%)$ patients reported having at least one first or second degree relative with IBD. In total, there were 54 affected sibling pairs, 18 parent-child affected pairs, and 24 second degree affected relatives pairs included in this cohort. UC patients were included in a single cohort because of the low incidence of UC in Belgium and Northern France and hence the low recruitment rate of UC in our centres. Subsequently, a population of 318 trios (one affected offspring and both parents) from the University Hospital Gasthuisberg, Leuven, was analysed to perform the transmission disequilibrium test (TDT). This population consisted of CD trios $(n=252)$, UC trios $(n=61)$, and indeterminate colitis (IC) trios $(n=5)$. A total of 216 CD trios were derived from the $334 \mathrm{CD}$ patients from cohort 1 . The 61 UC trios were derived from the 163 UC patients. CD and UC patients were
Table 2 Demographic and clinical characteristics of the ulcerative colitis study population $(n=163)$

\begin{tabular}{ll}
\hline Characteristic & \\
\hline Age $(y)($ mean $(S D))(n=163)$ & $29.78(12.8)$ \\
Sex $(\%$ female) $(n=163)$ & $78(47.8 \%)$ \\
Localisation $(n=154)$ & $41(26.6 \%)$ \\
$\quad$ Rectosigmoiditis & $54(35.1 \%)$ \\
$\quad$ Left sided colitis & $59(38.3 \%)$ \\
Pancolitis & $24(14.7 \%)$ \\
Familial disease $(n=163)$ & $28(17.5 \%)$ \\
Surgery ( $n=160)$ & $42(26.1 \%)$ \\
Extraintestinal manifestations $(n=161)$ & $34(22.5 \%)$ \\
Smoking at diagnosis $(n=151)$ & \\
\hline
\end{tabular}

diagnosed according to clinical, radiological, endoscopic, and pathological criteria, as previously described. ${ }^{24}$ The following clinical characteristics were analysed: age at diagnosis, sex, family history, disease location, surgery, smoking, and extraintestinal manifestations (tables 1,2). CD location and behaviour were assessed according to the Vienna classification (table 1). ${ }^{25}$ Informed written consent was obtained from all study participants. This study was conducted after review and approval of the ethics committees of Gasthuisberg, Leuven, and Erasme Hospitals, Brussels.

\section{Serological marker ASCA}

Anti-Saccharomyces cerevisiae antibody (ASCA) was measured by a standardised ELISA using mannan immobilised on the solid phase of a microtitre plate, according to the manufacturer's instructions, as previously described (Medipan Diagnostica, Selchow, Germany). ${ }^{26}$ Qualitative evaluation of the results was assessed by calculating the binding index (BI): BI = OD ( sample)/OD (cut off control). ASCA IgG and IgA were considered positive at a $\mathrm{BI}>1.0$.

\section{Genotyping}

DNA was extracted from whole venous blood from all patients and stored at $-80^{\circ} \mathrm{C}$.

\section{NOD2 genotype}

All individuals were genotyped for the three single nucleotide polymorphisms (SNPs) associated with CD in the NOD2 gene: Arg702Trp (also referred to as SNP8, GenBank accession No G67950), Gly908Arg ( SNP12, GenBank accession No

\begin{tabular}{|c|c|c|c|}
\hline Characteristic & $\begin{array}{l}\text { Cohort } 1 \\
(n=334)\end{array}$ & $\begin{array}{l}\text { Cohort } 2 \\
(n=114)\end{array}$ & p Value* \\
\hline Age at diagnosis (y) (mean (SD)) & $26.6(10.3)$ & $28.9(12.4)$ & 0.044 \\
\hline Sex (\% female) & $198(59.3 \%)$ & $50(43.8 \%)$ & 0.003 \\
\hline \multicolumn{4}{|l|}{$\begin{array}{l}\text { Localisation } \\
\text { Lation }\end{array}$} \\
\hline Ileitis & $110(32.9 \%)$ & $33(28.9 \%)$ & NS \\
\hline Ileocolitis & $179(53.6 \%)$ & $63(55.3 \%)$ & NS \\
\hline Colitis & $45(13.5 \%)$ & $18(15.8 \%)$ & NS \\
\hline Anal involvement & $133(39.8 \%)$ & $36(31.6 \%)$ & NS \\
\hline Upper involvement & $29(8.7 \%)$ & $8(7.0 \%)$ & NS \\
\hline \multicolumn{4}{|l|}{$\begin{array}{l}\text { Behaviour } \\
\text { Bentil }\end{array}$} \\
\hline Non-stricturing, non-penetrating & $77(23.1 \%)$ & $18(15.8 \%)$ & NS \\
\hline Stricturing & $173(51.8 \%)$ & $56(49.1 \%)$ & NS \\
\hline Penetrating & $84(25.1 \%)$ & $40(35.1 \%)$ & 0.042 \\
\hline Familial disease & $192(57.5 \%)$ & $13(11.4 \%)$ & $<0.001$ \\
\hline Surgery & $198(59.3 \%)$ & $64(56.1 \%)$ & NS \\
\hline Smoking & $153(45.8 \%)$ & $43(37.7 \%)$ & NS \\
\hline Extraintestinal manifestations & $117(35.0 \%)$ & $39(34.2 \%)$ & NS \\
\hline ASCA & $176(52.7 \%)$ & $53(46.5 \%)$ & NS \\
\hline
\end{tabular}

*p values are adjusted for familial correlation.

ASCA, anti-Saccharomyces cerevisiae antibody. 

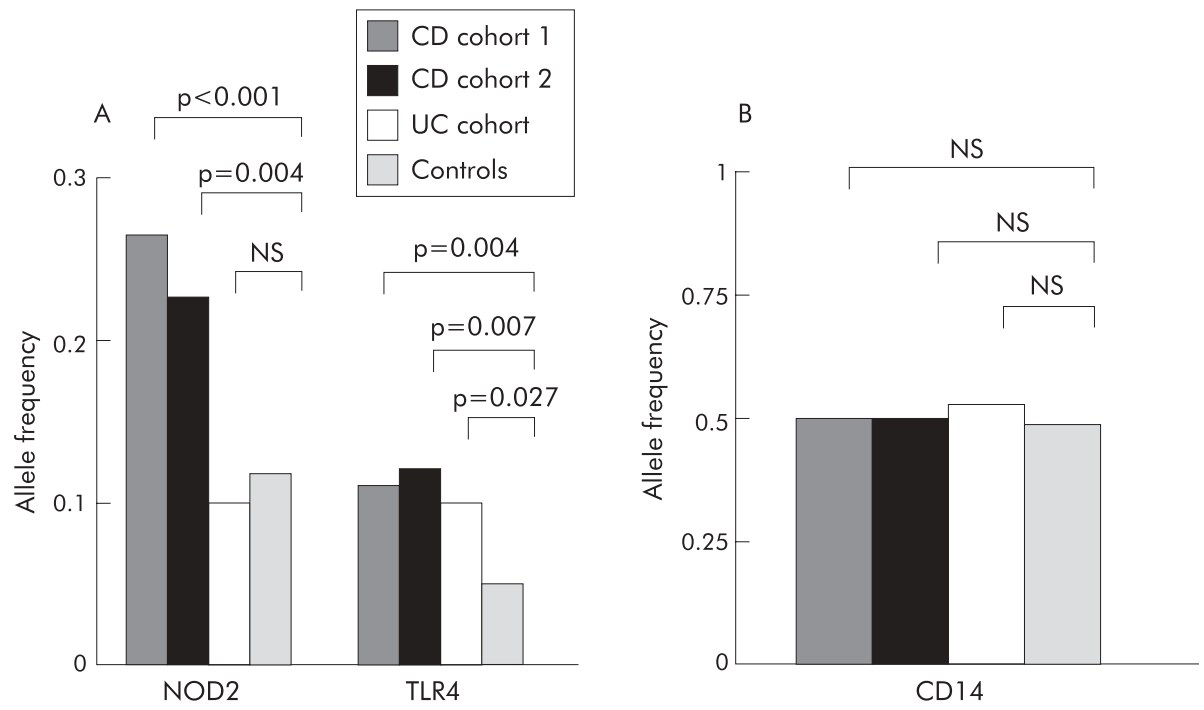

Figure 1 (A) Allele frequencies for the NOD2 variants (Arg702Trp, Gly908Arg, and Leu1007fsinsC) and the toll-like receptor 4 (TLR4) Asp299Gly polymorphism in the Crohn's disease (CD) cohort 1, CD cohort 2, ulcerative colitis (UC) cohort, and controls. (B) Allele frequencies for the CD14 C $-260 \mathrm{~T}$ promoter polymorphism in the four groups.

G67950), and Leu1007fsinsC (SNP13, Genbank accession No G67955). All DNA amplifications were carried out in $15 \mu \mathrm{l}$ polymerase chain reaction (PCR) reactions. For Arg702Trp, 35 PCR cycles at an annealing temperature of $56^{\circ} \mathrm{C}$ were performed with primers $5^{\prime}$ AGA TCA CAG CAG CCT TCC TG 3' (forward) and 5' CAC GCT CTT GGC CTC ACC-3' (reverse), followed by $M s p$ I digestion at $37^{\circ} \mathrm{C}$ overnight, resulting in visualisation of either $54+76+20+35$ bp bands (wild-type) or $130+20+35$ bp bands (mutated allele) on a $3 \%$ agarose gel. Gly908Arg was amplified using primers 5' CCC AGC TCC TCC CTC TTC- $3^{\prime}$ and $5^{\prime}$ AAG TCT GTA ATG TAA AGC CAC-3' (annealing temperature $55^{\circ} \mathrm{C}, 35$ cycles), followed by HhaI digestion, resulting in an intact fragment for the wild-type (380 bp) or two bands ( $138 \mathrm{bp}$ and $242 \mathrm{bp}$ ) for the variant. For Leul007insC, primers used were forward 5' GGC AGA AGC CCT CCT GCA GGG CC-3' and reverse 5' CCT CAA AAT TCT GCC ATT CC-3', followed by ApaI digestion at $25^{\circ} \mathrm{C}$ overnight, resulting in an intact band of 151 bp (wild-type allele) or two bands of $131+20 \mathrm{bp}$ (fs3020insC) (annealing $55^{\circ} \mathrm{C}, 30$ cycles $)$.

\section{Toll-like receptor 4 and CD 4 genotypes}

The principle of the method is based on analysis of melting curves generated by Taqman probe hybridisation on a PCR preamplified region of interest, in an "all-in-one" reaction. ${ }^{27}$ Primers and probes were designed with the freeware Meltcalc v2.0 demo (www.melcalc.de) and purchased by Eurogentec (Brussels, Belgium). Briefly, for detection of the D299G TLR4 polymorphism, $100 \mathrm{nM}$ of 5' CTA GAG GGC CTG TGC AAT TTG ACC-3' (forward primer), Fam-ACT ACT ACC TCG ATG
GTA-DarqQuencher (probe), and $900 \mathrm{nM}$ of 5' CCC TTT CAA TAG TCA CAC TCA CCA GG-3' (reverse primer) were combined with $1 \times$ Platinum Quantitative SuperMix-UDG (Invitrogen, Merelbeke, Belgium) and $100 \mathrm{ng}$ of patient DNA in a $25 \mu \mathrm{l}$ reaction volume. For detection of the CD14 "C $-260 \mathrm{~T}^{\prime}$ promoter polymorphism, $100 \mathrm{nM}$ of $5^{\prime}$ CCC TTC CTT TCC TGG AAA TAT TGC A-3' (reverse primer), Fam-GGA CCG TAA CAG GAA G-DarqQuencher (probe), and $900 \mathrm{nM}{ }^{-}$of $5^{\prime}$ TGC CAG GAG ACA CAG AAC CCT AGA T 3' (forward primer) were used under the same conditions as described above. PCR conditions were as follows: step $1,50^{\circ} \mathrm{C}$ (two minutes); step 2 , $95^{\circ} \mathrm{C}$ (two minutes); step $3(40 \times), 95^{\circ} \mathrm{C}$ (10 seconds), $65^{\circ}$ (30 seconds), and $72^{\circ} \mathrm{C}\left(20\right.$ seconds); step $4,95^{\circ} \mathrm{C}$ (two minutes); and step $5,20-70^{\circ} \mathrm{C}$ (ramping time 20 minutes). All experiments were performed on a 7700 Taqman apparatus (Applied Biosystem, Anderlecht, Belgium). Information collected during the melting curve step was analysed with SDS software version 1.7. The multicomponent file obtained was then exported and analysed with the dissociation curve software (Applied Biosystem).

\section{Statistical analyses}

Allele frequencies were tested for the Hardy-Weinberg equilibrium. Cases and controls were compared using Pearson's $\chi^{2}$ test. Statistical analyses were performed using Genmod procedure in SAS/STAT taking into account the familial structure (SAS V8-Genmod procedure). Simple and multiple logistic regression models were used to analyse genotype-phenotype relationships, accounting for familial structure present in the data, with compound symmetry

Table 3 Toll-like receptor 4 (TLR4) genotypes in the study populations

\begin{tabular}{|c|c|c|c|c|}
\hline & $\begin{array}{l}\text { CD cohort } 1 \\
(n=334)^{*}\end{array}$ & $\begin{array}{l}\text { CD cohort } 2 \\
(n=113)^{* *}\end{array}$ & $\begin{array}{l}\text { UC } \\
(n=163)^{* * *}\end{array}$ & $\begin{array}{l}\text { Controls } \\
(n=139)\end{array}$ \\
\hline \multicolumn{5}{|l|}{ Genotype } \\
\hline Wild-type & $265(79.3 \%)$ & $88(77.9 \%)$ & 133 (81.6\%) & $126(90.6 \%)$ \\
\hline Heterozygous & $65(19.5 \%)$ & $24(21.2 \%)$ & 28 (17.2\%) & $12(8.6 \%)$ \\
\hline $\begin{array}{l}\text { Homozygous mutant } \\
\text { Allele frequencies }\end{array}$ & $4(1.2 \%)$ & $1(0.9 \%)$ & $2(1.2 \%)$ & $1(0.8 \%)$ \\
\hline Minor allele & $10.9 \%$ & $11.5 \%$ & $9.8 \%$ & $5.0 \%$ \\
\hline
\end{tabular}


Table 4 NOD2 genotypes in the study populations

\begin{tabular}{|c|c|c|c|c|}
\hline & $\begin{array}{l}\text { CD cohort } 1 \\
(n=334) t+t\end{array}$ & $\begin{array}{l}\text { CD cohort } 2 \\
(n=114) \dagger \dagger\end{array}$ & $\begin{array}{l}\text { UC } \\
(n=163)\end{array}$ & $\begin{array}{l}\text { Controls } \\
(n=140)\end{array}$ \\
\hline \multicolumn{5}{|l|}{ Genotype } \\
\hline Wild-type & $184(55.1 \%)$ & $67(58.8 \%)$ & $135(82.9 \%)$ & $109(77.8 \%)$ \\
\hline Heterozygous & $122(36.5 \%)$ & $41(35.9 \%)$ & $25(15.3 \%)$ & $28(20.0 \%)$ \\
\hline $\begin{array}{l}\text { Homozygous mutant or } \\
\text { compound heterozygous }\end{array}$ & $28(8.4 \%)$ & $6(5.3 \%)$ & $3(1.8 \%)$ & $3(2.2 \%)$ \\
\hline \multicolumn{5}{|l|}{ Allele frequencies (minor allele) } \\
\hline Arg702Trp & $12.3 \% *$ & $11.4 \%$ ** & $5.5 \%$ *** & $6.8 \%$ \\
\hline Gly908Arg & $5.7 \% *$ & $3.9 \% * *$ & $2.4 \% * \star *$ & $2.1 \%$ \\
\hline Leu $1007 f_{s i n s} C$ & $8.9 \% *$ & $8.0 \%$ ** & $1.5 \%$ *** & $2.5 \%$ \\
\hline
\end{tabular}

correlation working assumptions whether appropriate (SAS V8-Genmod procedure). Results are expressed as odds ratios (OR) with corresponding 95\% confidence intervals (95\% CI). Significance level was predefined at 0.05 . For calculation of the genotype relative risk, we first deduced the genotype absolute risk (GAR) of the different genotypes for the development of CD. Assuming a population prevalence of $1 / 1000$ for CD, GAR for development of CD in a wild-type individual is $\mathrm{GAR}_{\text {wild-type }}=p_{\text {wild type }} \times 0.1 \%$, with $p$ being the relative proportion of $\mathrm{CD}$ patients versus controls carrying the wild type $(-/-)$ genotype. The same calculations were made for heterozygous and homozygous mutant genotypes. The genotype relative risk (GRR) was obtained by assuming that the $\mathrm{GRR}_{\text {wild-type }}=1$ and $\mathrm{GRR}_{\text {heterozygous }}=\mathrm{GAR}_{\text {heterozygous }} /$

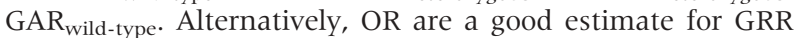
and give similar values when the probability of the outcome of interest is small, as in this case with $C D$ where the population prevalence is low. ${ }^{28}$

\section{RESULTS}

Demographic and clinical characteristics of the CD (cohorts 1 and 2) and UC patients are shown in tables 1 and 2. There were more women than men in CD cohort 1 , with a younger age at diagnosis and a higher prevalence of a familial history. More patients suffered from penetrating diseases in CD cohort 2 (tables 1,2 ).

We first examined the prevalence of the TLR4 Asp299Gly genotype in CD and UC patients. There were significantly more CD patients in cohort 1 carrying the TLR4 Asp299Gly variant compared with the control population $(20.7 \%$ v $9.4 \%$; $\mathrm{p}=0.012)$. This was also confirmed in CD cohort $2(22.1 \% v$ $9.4 \% ; \mathrm{p}=0.017$ ) (table 3). Mutant allele frequency was significantly higher in CD patients from cohorts 1 ( $11 \% \mathrm{v} \%$, OR 2.31 (95\% CI 1.28-4.17); $\mathrm{p}=0.004)$ and $2(12 \% v 5 \%$, OR 2.45 (95\% CI 1.248-4.816); $\mathrm{p}=0.007$ ) compared with the control population (combined cohorts 1 and 2: $11 \% v 5 \%$, OR 2.35 (95\% CI 1.32-4.18); $\mathrm{p}=0.001$ ) (fig 1A). Similarly, for UC patients, the allele frequency of the TLR4 polymorphism was

Table 5 Transmission disequilibrium test shows overtransmission of the Toll-like receptor 4 (TLR4) polymorphism to $C D$ patients

\begin{tabular}{|c|c|c|c|c|}
\hline & \multirow[b]{2}{*}{ No of trios } & \multicolumn{2}{|c|}{ TLR4 Asp299Gly } & \multirow{2}{*}{$\begin{array}{l}\text { p Value } \\
(\mathrm{df}=1)\end{array}$} \\
\hline & & Transmitted & Untransmitted & \\
\hline $\begin{array}{l}C D \text { patients } \\
\text { IBD patients }\end{array}$ & $\begin{array}{l}252 \\
318\end{array}$ & $\begin{array}{l}52 \\
64\end{array}$ & $\begin{array}{l}29 \\
38\end{array}$ & $\begin{array}{l}0.01 \\
0.01\end{array}$ \\
\hline
\end{tabular}

Inflammatory bowel disease (IBD) trios include Crohn's disease (CD) trios $(n=252)$, ulcerative colitis (UC) trios $(n=61)$, and indeterminate colitis (IC) trios $(n=5)$. significantly higher than in controls ( $10 \% v 5 \%$, OR 2.05 (95\% CI 1.072-3.930); $\mathrm{p}=0.027$ ) (fig lA). TLR4 allele frequencies were in Hardy-Weinberg equilibrium in all cohorts and controls. In order to further assess the relevance of the association of the TLR4 Asp299Gly polymorphism with CD, TDT testing was performed on 318 IBD trios (table 5). Overtransmission of the TLR4 Asp299Gly polymorphism from heterozygous parents to affected children was observed in the $\mathrm{CD}$ trios, with 52 transmissions versus 29 non-transmissions $\left(\chi^{2}\right.$ 6.53, $\left.\mathrm{df}=1, \mathrm{p}=0.01\right)$. When the $\mathrm{CD}, \mathrm{UC}$, and IC trios were combined, this overtransmission was still observed (64 transmissions versus 38 non-transmissions; $\chi^{2} 6.63, \mathrm{df}=1$, $\mathrm{p}=0.01)$. We then examined whether this TLR4 polymorphism could be related to particular CD or UC phenotypes. Detailed analysis did not show any association of the TLR4 polymorphism with either CD or UC patient subgroups (data not shown). Thus the TLR4 Asp299Gly polymorphism was significantly associated with CD and UC without influencing disease phenotype.

TLR4 and NOD2 are both PRRs involved in bacterial recognition. ${ }^{8}$ Three NOD2 variants (Arg702Trp, Gly908Arg, and Leul007fsinsC) have been reported previously to be associated with $\mathrm{CD} .{ }^{11}{ }^{12}$ We then sought to explore the influence of the interaction between the TLR4 Asp299Gly polymorphism and the three NOD2 variants on the relative risk (RR) of $\mathrm{CD}$ and on $\mathrm{CD}$ phenotype. Consistent with previous studies, all three NOD2 polymorphisms were significantly associated with $\mathrm{CD}$, as observed in cohort 1 (44.9\% v 22.2\%, OR 4.4 (95\% CI 2.99-6.48); $\mathrm{p}<0.001)$ and cohort $2(41.2 \% \quad v \quad 22.2 \%$, OR 2.19 (95\% CI $1.36-3.51)$; $\mathrm{p}=0.004$ ) but were not associated with UC (OR 0.76 (95\% CI 0.45-1.27); $\mathrm{p}=0.296$ ) (table 4). When examining the interaction between the TLR4 Asp299Gly polymorphism and NOD2 genotype (table 6), no interaction between TLR4 and NOD2 was observed as the allele frequency of the TLR4 Asp299Glyc risk allele did not differ whether NOD2 variants were absent $(10.9 \%)$ or present $(10.2 \%)$. The RR of carrying one variant in TLR4 or NOD2 was 2.652 and 2.528, respectively. Table 7 shows the RR of carriers heterozygous or homozygous for TLR4 or NOD2 variants. The RR of carriers

Table 6 Stratification of Toll-like receptor 4 (TLR4) allele frequency by NOD2 genotype

\begin{tabular}{ll}
\hline NOD2 genotype in CD & $\begin{array}{l}\text { TLR4 Asp299Gly } \\
\text { allele frequency }\end{array}$ \\
\hline $\begin{array}{l}\text { Wild-type } \\
\text { Heterozygous, homozygous, and } \\
\text { compound heterozygous combined }\end{array}$ & $10.9 \%$ \\
\hline CD, Crohn's disease. & \\
\hline
\end{tabular}


Table 7 Relative risks (expressed as odds ratios) for the Toll-like receptor 4 (TLR4) and NOD2 genotypes

\begin{tabular}{lccc}
\hline & Wild-type & Heterozygous & Homozygous mutant \\
\hline NOD2 mutations & 251 & 163 & 34 \\
CD & 109 & 28 & 3 \\
Controls & 1 & $2.528(1.562-4.11)$ & $4.199(1.41-20.513)$ \\
OR (95\% Cl) & 353 & 89 & 5 \\
TLR4 Asp299Gly & 126 & 12 & 1 \\
CD & 1 & $2.652(1.356-5.274)$ & $1.780(0.201-40.619)$ \\
Controls & 1 & & \\
OR (95\% Cl) & &
\end{tabular}

$\mathrm{CD}$, Crohn's disease; $\mathrm{OR}$, odds ratio; $95 \% \mathrm{Cl}, 95 \%$ confidence interval.

For TLR4 Asp299Gly, one CD patient and one control could not be genotyped.

homozygous for both TLR4 and NOD2 variants could not be measured as there were no patients with this genotype combination. The RR of each of the NOD2 polymorphisms stratified by TLR4 genotype could not be calculated because of the limited sample size. Defining the RR of CD when carrying no variants in TLR4 or NOD2 as 1 , the RR in carriers of either TLR4 or NOD2 variant was 3.071, and the RR in carriers of both TLR4 and NOD2 variants was 4.73. Thus the TLR4 Asp299Gly polymorphism increases the RR of developing CD either alone or when combined with the NOD2 polymorphisms.

Phenotypic analysis demonstrated an association of the NOD2 variants with small bowel involvement and fibrostenotic disease, and a negative association with colonic involvement. ${ }^{15}$ In our $\mathrm{CD}$ population (cohorts 1 and 2), multiple logistic regression showed a positive and negative association with ASCA (OR 1.94 (95\% CI 1.29-2.90); $\mathrm{p}=0.001$ ) and colonic involvement (OR 0.45 (95\% CI $0.24-$ $0.84) ; p=0.012)$, respectively. We then examined whether CD clinical characteristics were associated with any of the four genotypes (TLR4-/NOD2+, TLR4-/NOD2-, TLR4+/ NOD2+, and TLR4+/NOD2-). The NOD2+/TLR4- genotype was the only combination with a significant genotypephenotype association. Indeed, the NOD2+/TLR4- genotype was significantly associated with ASCA $(\mathrm{p}=0.003$; OR 1.92 (95\% CI 1.242-2.953)) and negatively associated with colitis $(\mathrm{p}=0.015$; OR 0.43 (95\% CI 0.211-0.848)).

Analysing SNP interactions influencing the level of expression and/or function of signalling molecules will allow an understanding of the phenotypic variation in LPS transduction. LPS may first interact with soluble or membrane bound CDl4 before binding to TLR $4{ }^{8}$ The recently described C-260T promoter polymorphism is associated with increased expression and levels of soluble CD14, which may further amplify LPS signalling. ${ }^{29}$ While reported to be associated with $\mathrm{CD}$ or $\mathrm{UC},{ }^{30}$ both the genotype and allele frequencies of this polymorphism were not higher in our CD (cohort 1 and 2) and UC patients compared with controls (fig 1B). Furthermore, this polymorphism, either alone or in combination with the Asp299Gly TLR4 polymorphism, was not associated with any CD or UC clinical characteristics.

\section{DISCUSSION}

IBD results from an abnormal innate mucosal immune response to gut microflora in a genetically susceptible host. ${ }^{31}$ In this study, we report on a novel genetic association between a polymorphism in the LPS receptor TLR4, Asp299Gly, and both CD and UC. Evaluating the association of the TLR4 Asp299Gly polymorphism with predefined clinical characteristics and biological markers failed to show any impact on a particular CD or UC phenotype. The genetic association of CD with NOD2 polymorphisms and TLR4 Asp299Gly clearly suggests disturbed interactions with Gram negative and Gram positive bacteria in the triggering of $\mathrm{CD}$.
Also, the association of this TLR4 variant with UC further supports the role of Gram negative bacteria in the pathogenesis of UC. ${ }^{32}$ Thus the novel association with the TLR4 polymorphism strongly suggests the genetic influence of PRRs in susceptibility to IBD.

The intestinal mucosa is continuously exposed to massive amounts of commensal and pathogenic bacteria but will hardly ever initiate a mucosal immune response to bacterial products such as LPS. The IEC is a major player in the regulation of intestinal immune response to luminal antigens. Low level TLR4 expression in IECs is believed to account for normal mucosal hyporesponsiveness to LPS. ${ }^{33}$ In line with these observations, it would be expected that the TLR4 Asp299Gly polymorphism associated with a deficient LPS response should prevent mucosal immune response to Gram negative bacteria. However, TLR4 is induced by proinflammatory cytokines and is highly expressed in IECs, resident macrophages, and dendritic cells in inflamed mucosa of IBD patients. ${ }^{18} 19$ Dendritic cell maturation and the development of adaptive immunity seem to require correct TLR4 signalling. Disruption of TLR4 signalling could engender an inappropriate innate and adaptive immune response necessary to eradicate pathogens which would result in a more severe inflammation. ${ }^{34}$ This is well illustrated in $\mathrm{CEH} / \mathrm{HeJ}$ and $\mathrm{C} 57 \mathrm{BL} / 10 \mathrm{ScCR}$ mice which bear loss of function mutation of TLR4 and are highly susceptible to dextran sodium sulphate induced colitis. ${ }^{35}$ Further evidence comes from generation of the derived strain, CEH/HeJbir mice, which develop spontaneous colitis and demonstrate highly reactive $\mathrm{B}$ and $\mathrm{T}$ cells to conventional antigens of their enteric bacterial flora. ${ }^{36-38}$ In humans, although the functional relevance of the TLR4 Asp299Gly polymorphism has been carefully examined in vivo and in transfection experiments in vitro, ${ }^{20}$ a recent study has questioned the influence of this polymorphism on LPS signalling in human monocytes isolated from wild-type and heterozygous healthy carriers. ${ }^{23}$ In truth, these results were highly expected as only in vitro transfection experiments can reveal the functional significance of a single polymorphism. While the TLR4 Asp299Gly polymorphism might have relative in vivo penetrance given that many transducing molecules involved in the LPS signalling pathway must also bear functional polymorphisms and influence the in vivo LPS response, ${ }^{20} 23$ this polymorphism could predispose individuals to an altered innate immune response and chronic inflammation.

The TLR4 gene was not found to lie within a chromosomal region linked to $\mathrm{CD}$ in genome wide linkage studies. This is however not surprising as linkage methodologies in complex diseases can miss significant loci, and it is anticipated that biologically relevant disease associations may be established for IBD in chromosomal regions that are not previously implicated through linkage studies. ${ }^{15}$ Moreover, as CD is a heterogeneous polygenic disease, it is expected that association studies will reveal various sets of susceptible genes 
depending on the ethnic background of the study populations. It is remarkable that the NOD2 mutations associated with CD in the USA and Western Europe are indeed not reported to be associated with CD in Japan. ${ }^{39}$ Similarly, preliminary reports indicate that the TLR4 Asp299Gly polymorphism does not seem to be associated with CD in England and Scotland while positive associations were observed in three independent cohorts in Belgium and the Netherlands. ${ }^{40-42}$ Further genetic studies should resolve the impact of the PRR in the susceptibility of CD, depending on ethnic background.

In conclusion, we identified an association of the TLR4 Asp299Gly polymorphism in two independent cohorts of CD and in UC. Our findings support the importance of PRRs in the genetic control of LPS signalling in IBD. Studying SNPs in molecules involved in bacterial recognition will be essential to understand individual responses to bacterial components and define genetic backgrounds at risk of IBD.

\section{ACKNOWLEDGEMENTS}

Supported by the Belgium FNRS (to DF) and the FWO (to SV).

\section{Authors' affiliations}

D Franchimont*, T Gustot, E Quertinmont, A Van Gossum, J Devière, Department of Gastroenterology, Erasme University Hospital, Brussels, Belgium

S Vermeire*, M Pierik, P Rutgeerts, Department of Gastroenterology, University Hospital Gasthuisberg, Leuven, Belgium

H El Housni, M Abramowicz, Department of Genetics and IRIBHM, Erasme University Hospital, ULB, Brussels, Belgium

K Van Steen, Centre for Statistics, Limburgs Universitair Centrum, Diepenbeek, Belgium

${ }^{*} D$ Franchimont and S Vermeire contributed equally to this work.

\section{REFERENCES}

1 Elson CO, Cong Y, Brandwein S, et al. Experimental models to study molecular mechanisms underlying intestinal inflammation. Ann N Y Acad Sci 1998;859:85-95.

2 Rutgeerts P, Goboes K, Peeters M, et al. Effect of faecal stream diversion on recurrence of Crohn's disease in the neoterminal ileum. Lancet 1991;338:771-4.

3 Podolsky DK. Inflammatory bowel disease. N Engl J Med 2002;347:417-29.

4 Duchmann R, May E, Heike $M$, et al. T cell specificity and cross reactivity towards enterobacteria, bacteroides, bifidobacterium, and antigens from resident intestinal flora in humans. Gut 1999:44:812-18.

5 Landers CJ, Cohavy O, Misra R, et al. Selected loss of tolerance evidenced by Crohn's disease-associated immune responses to auto- and microbial antigens. Gastroenterology 2002;123:689-99.

6 Farrell RJ, Peppercorn MA. Ulcerative colitis. Lancet 2002;359:331-40.

7 Shanahan F. Crohn's disease. Lancet 2002;359:62-9.

8 Medzhitov R, Biron CA. Innate immunity. Curr Opin Immunol 2003;15:2-4

9 Inohara N, Ogura Y, Chen FF, et al. Human Nodl confers responsiveness to bacterial lipopolysaccharides. J Biol Chem 2001;276:2551-4.

10 Inohara N, Ogura Y, Nunez G. Nods: a family of cytosolic proteins that regulate the host response to pathogens. Curr Opin Microbiol 2002;5:76-80.

11 Hugot JP, Chamaillard M, Zouali $\mathrm{H}$, et al. Association of NOD2 leucine-rich repeat variants with susceptibility to Crohn's disease. Nature 2001;411:599-603.

12 Ogura $\mathrm{Y}$, Bonen DK, Inohara N, et al. A frameshift mutation in NOD2 associated with susceptibility to Crohn's disease. Nature 2001:411:603-6.

13 Bonen DK, Ogura Y, Nicolae DL, et al. Crohn's disease-associated NOD2 variants share a signaling defect in response to lipopolysaccharide and peptidoglycan. Gastroenterology 2003;124:140-6.
14 Inohara N, Ogura Y, Fontalba A, et al. Host recognition of bacterial muramyl dipeptide mediated through NOD2. Implications for Crohn's disease. J Biol Chem 2003;278:5509-12.

15 Watts DA, Satsangi J. The genetic jigsaw of inflammatory bowel disease. Gut 2002;50:31-6.

16 Medzhitov R. Toll-like receptors and innate immunity. Nat Rev Immunol 2001;1:135-45.

17 Qureshi ST, Lariviere L, Leveque G, et al. Endotoxin-tolerant mice have mutations in Toll-like receptor 4 (T/r4). J Exp Med 1999;189:615-25.

18 Cario E, Podolsky DK. Differential alteration in intestinal epithelial cell expression of toll-like receptor 3 (TLR3) and TLR4 in inflammatory bowel disease. Infect Immun 2000;68:7010-17.

19 Hausmann M, Kiessling S, Mestermann S, et al. Toll-like receptors 2 and 4 are up-regulated during intestinal inflammation. Gastroenterology 2002;122:1987-2000.

20 Arbour NC, Lorenz E, Schutte BC, et al. TLR4 mutations are associated with endotoxin hyporesponsiveness in humans. Nat Genet 2000;25:187-91

21 Kiechl S, Lorenz E, Reindl M, et al. Toll-like receptor 4 polymorphisms and atherogenesis. N Engl J Med 2002;347:185-92.

22 Lorenz E, Mira JP, Frees KL, et al. Relevance of mutations in the TLR4 receptor in patients with gram-negative septic shock. Arch Intern Med 2002; 162:1028-32

23 Erridge C, Stewart J, Poxton IR. Monocytes heterozygous for the Asp299Gly and Thr399|le mutations in the Toll-like receptor 4 gene shows no deficit in the lipopolysaccharride signaling. J Exp Med 2003;197:1787-91.

24 Lennard-Jones JE. Classification of inflammatory bowel disease. Scand J Gastroenterol Suppl 1989;170:2-6.

25 Gasche C, Scholmerich J, Brynskov J, et al. A simple classification of Crohn's disease: report of the Working Party for the World Congresses of Gastroenterology, Vienna 1998. Inflamm Bowel Dis 2000;6:8-15.

26 Vermeire S, Joossens S, Peeters M, et al. Comparative study of ASCA (AntiSaccharomyces cerevisiae antibody) assays in inflammatory bowel disease. Gastroenterology 2001;120:827-33.

27 Housni EH, Heiman P, Parma Vassart G. Dividing the quantity by two or "how to detect SNP or mutations with a single Taqman probe". The example of factor V Leiden and prothrombin 20210A mutations. Clin Chem 2003;49:1669-72.

28 Hampe J, Cuthbert A, Croucher PJ, et al. Association between insertion mutation in NOD2 gene and Crohn's disease in German and British populations. Lancet 2001;357:1925-8.

29 Baldini M, Lohman IC, Halonen $M$, et al. A Polymorphism* in the $5^{\prime}$ flanking region of the CD14 gene is associated with circulating soluble CD14 levels and with total serum immunoglobulin E. Am J Respir Cell Mol Biol 1999;20:976-83.

30 Klein W, Tromm A, Griga T, et al. A polymorphism in the CD14 gene is associated with Crohn disease. Scand J Gastroenterol 2002;37:189-91.

31 Elson CO. Genes, microbes, and T cells-new therapeutic targets in Crohn's disease. N Engl J Med 2002;346:614-16.

32 Campieri M, Gionchetti P. Bacteria as the cause of ulcerative colitis. Gut 2001;48:132-5.

33 Abreu MT, Vora P, Faure E, et al. Decreased expression of Toll-like receptor-4 and MD-2 correlates with intestinal epithelial cell protection against dysregulated proinflammatory gene expression in response to bacterial lipopolysaccharide. J Immunol 2001;167:1609-16.

34 Barton GM, Medzhitov R. Control of adaptive immune responses by Toll-like receptors. Curr Opin Immunol 2002; 14:380-3.

35 Mahler M, Bristol IJ, Leiter EH, et al. Differential susceptibility of inbred mouse strains to dextran sulfate sodium-induced colitis. Am J Physiol 1998;274:G544-51.

36 Brandwein SL, McCabe RP, Cong Y, et al. Spontaneously colitic $\mathrm{C} 3 \mathrm{H} / \mathrm{HeJBir}$ mice demonstrate selective antibody reactivity to antigens of the enteric bacterial flora. J Immunol 1997;159:44-52.

37 Cong Y, Brandwein SL, McCabe RP, et al. CD4+ T cells reactive to enteric bacterial antigens in spontaneously colitic $\mathrm{C} 3 \mathrm{H} / \mathrm{HeJBir}$ mice: increased T helper cell type 1 response and ability to transfer disease. J Exp Med 1998;187:855-64.

38 Sundberg JP, Elson CO, Bedigian $\mathrm{H}$, et al. Spontaneous, heritable colitis in a new substrain of $\mathrm{C} 3 \mathrm{H} / \mathrm{HeJ}$ mice. Gastroenterology 1994; 107:1726-35.

39 Inoue N, Tamura K, Kinouchi Y, et al. Lack of common NOD2 variants in Japanese patients with Crohn's disease. Gastroenterology 2002;123:86-91.

40 Nimmo ER, Arnott IR, Drummond HE, et al. Mutations of the Toll-like receptor 4 and CDI 4 are not associated with susceptibility or disease behaviour in inflammatory bowel disease. Gastroenterology 2003;124:A373.

41 McGovern D, Van Heel D, Negoro K, et al. Innate immunogenetics and inflammatory bowel diseases. Gastroenterology 2003;124:A369.

42 Braat $H$, Dijgraaf $M$, Curvers $W$, et al. A functional single polymorphism of the TLR4 gene is correlated Crohn's disease but not with ulcerative colitis. Gastroenterology, 2003;124:A367 